\title{
GEOACOUSTIC PATTERNS OF THE GUAÍBA RIVER BOTTOM AND SUB-BOTTOM AND THEIR RELATIONSHIP WITH SEDIMENTARY AND HYDRODYNAMIC PROCESSES
}

\author{
Fernando Comerlato Scottá, Mauro Michelena Andrade, Vicente Oliveira Silva Junior, Natacha Oliveira, \\ Jair Weschenfelder, Eduardo Calixto Bortolin and José Carlos Nunes
}

\begin{abstract}
This work aimed at studying the bottom and sub-bottom geoacoustics of the Guaíba River, whose echo patterns are related to hydrodynamic patterns and sedimentary processes. A total of $324 \mathrm{~km}$ of seismic transects were surveyed using the Stratabox high-frequency $(10 \mathrm{kHz})$ profiler with concomitant imaging using a side-scan sonar in the northern and central areas of the Guaiba system. The records were interpreted with the aid of complementary data (bathymetry and bottom samples), and maps containing the spatial arrangement of echo-characters were developed. The echo-characters were classified into seven different types according to the presence of sediments controlled by the hydrodynamics of the system or modified by human action. In general, the echoes related to the deposition of fine sediments occurred in deeper areas, the navigation channel or surrounding areas. The echoes in the shallower areas presented strong acoustic reflectivity at sites with lower deposition of fine sediments and predominance of sandy sediments. The occurrence and morphology of asymmetric subaqueous dunes indicated a predominant north-to-south flow and a river behavior.
\end{abstract}

Keywords: shallow geophysics, sedimentology, hydrodynamics, geoprocessing

RESUMO. Este trabalho tem por objetivo o estudo geoacústico de fundo e subfundo do rio Guaíba, cujos padrões de ecos são relacionados aos padrões hidrodinâmicos e aos processos sedimentares atuantes. Foram levantados $324 \mathrm{~km}$ de perfis sísmicos em extensão, com o perfilador de alta frequência (10 kHz) Stratabox e concomitante imageamento com sonar de varredura lateral nas áreas norte e central do Guaíba. Os registros foram interpretados com 0 auxílio de dados complementares (batimetria e amostras de fundo) e foram confeccionados mapas com a disposição espacial dos eco-caráteres. Os eco-caráteres foram classificados em sete diferentes tipos, de acordo com a presença de sedimentos controlados pela hidrodinâmica do sistema ou modificados pela ação humana. De uma forma geral, os ecos relacionados à deposição de sedimentos finos ocorrem nas áreas mais profundas, no canal de navegação ou adjacências. Os ecos nas áreas mais rasas apresentam forte refletividade acústica, em locais com menor deposição de sedimentos finos e predomínio de sedimentos arenosos. A ocorrência e morfologia de dunas subaquosas assimétricas indicam um fluxo preponderante no sentido norte-sul e um comportamento fluvial do sistema aquático.

Palavras-chave: geofísica rasa, sedimentologia, hidrodinâmica, geoprocessamento.

Universidade Federal do Rio Grande do Sul - UFRGS, Instituto de Geociências, Avenida Bento Gonçalves, 9500, 91540-000 Porto Alegre, RS, Brazil - E-mails: fernandoscotta.sema@gmail.com, mauromichelena@gmail.com, voliveirasjr@gmail.com, natoliveiran@gmail.com, jair.weschenfelder@ufrgs.br, eduardo_bortolin_22@hotmail.com, jose.nunes@ufrgs.br 


\section{INTRODUCTION}

Integrated management of the coastal zone and its various associated environments requires precise spatial datasets covering large areas, which are sometimes inaccessible by direct sampling methods (Kotilainen \& Kaskela, 2017). In the submerged environment of coastal areas, seismic data sampling is important and can help in the management of these environments since it allows the recognition of the type of bottom and sub-bottom, knowing sedimentary processes, and also infer in the environment hydrodynamics (Catanzaro et al., 2004; Veronez Jr et al., 2009a, 2009b).

The first studies using seismic data were carried out in marine environments (Damuth, 1975; Damuth \& Hayes, 1977) and later were applied in shallow areas, facing a greater navigability restriction imposed to large vessels (e.g. Baptista Neto et al., 1996; Nitsche et al., 2004). The advancement of technology has contributed to a larger portability of geophysical equipment, allowing the development of studies in restricted areas that were previously inaccessible onboard large vessels (Souza, 2006). In these environments, geoacoustic sensors have been increasingly used since the late 1990s (Clarke et al., 1996).

In Brazil, several seismic studies have been conducted in areas of bays, lakes, rivers, and estuaries (Quaresma et al., 2000; Catanzaro et al., 2004; Hatushika et al., 2007; Paolo \& Mahiques, 2008; Veronez Jr et al., 2009a, 2009b; Quaresma et al., 2011; Marino et al., 2013; Silva et al., 2014; Barros et al., 2017). These research works have identified and classified echo-characters and sonographic patterns, which can be defined according to their reflection patterns (seismic facies). Thus, the echo-character can be correlated with the size and texture of the bottom sediments (Veronez Jr et al., 2009a).

In the state of Rio Grande do Sul (RS), southern Brazil, several studies carrying out seismic surveys have been conducted in Patos Lagoon (Toldo Jr et al., 2000; Weschenfelder et al., 2006; Weschenfelder et al., 2010; Baitelli, 2012; Weschenfelder et al., 2014; Santos-Fischer et al., 2016; Bortolin, 2017; Bortolin et al., 2019). These works mainly aimed at constructing an evolutionary model of Patos Lagoon (PL), a large water body with an area of $10,000 \mathrm{~km}^{2}$. Seismic records revealed channels that deeply dissected the region before the formation of the current coastal plain (Weschenfelder et al., 2010; Baitelli, 2012; Weschenfelder et al., 2014). In another study, Weschenfelder et al. (2006) indicated the PL sectors that contain gas accumulation, which were areas with paleo-topographic lows associated with river channels and valleys that were developed in the RS coastal plain during the regressive/transgressive events from the Quaternary.

More recently, studies relating sonographic patterns to the bottom sediment were conducted in the RS coastal areas. Oliveira (2017) analyzed the southern portion of the RS continental shelf near the PL mouth and identified acoustic anomalies as a response to the presence of interstitial gas in the sediment. Bexiga (2016) also carried out a similar study in the PL Southern Sector, describing three echo patterns and the presence of gas in seismic profiles. Moreover, Silva Jr. (2017) analyzed some of the seismic data used here and preliminarily identified some echo-facies patterns from the northern portion of the Guaíba River.

Important RS water bodies lack geoacoustic studies to identify the bottom and sub-bottom depositional architecture as well as sedimentary characteristics and processes. Thus, the objective of this work is to study the bottom and sub-bottom geoacoustics of the Guaíba River, whose echo patterns are related to hydrodynamic patterns and sedimentary processes.

\section{STUDY AREA}

The Guaíba system is a water body of about $496 \mathrm{~km}^{2}$ (Fig. 1) located next to the city of Porto Alegre, capital of RS. It is formed by the confluence of the Jacuí, Sinos, Caí, and Gravataí rivers, receiving the drainage of nine sub-basins that extend through the center and northeast of RS, covering an area of approximately $84,763 \mathrm{~km}^{2}$. It supplies water to the cities of Porto Alegre, Guaíba, Barra do Ribeiro, and Viamão. In addition to the water supply, it has several uses such as fishing, leisure, and cargo and people transportation.

In terms of bathymetry, the Guaíba River presents an average depth of $2 \mathrm{~m}$ (Nicolodi, 2007), but with recorded values over 30 $\mathrm{m}$ near the city of Itapuã (CHM, 2012). However, its important morphological characteristic is the presence of a navigation channel that mainly varies between 4 and $8 \mathrm{~m}$ deep (DNAEE, 1983), reaching $14 \mathrm{~m}$ deep at some sites.

The definition of Guaiba Lake or River is the subject of frequent debates in the most diverse sectors of our society. The Guaíba system is officially defined as a river by the Brazilian Navy (CHM, 2012) and as a lake by the city hall of Porto Alegre (DMAE, 2018). Academic divergences are also frequent. Menegat \& Carraro (2009) define the Guaíba system as a lake and state that its flow only occurs superficially, a common feature of lakes. Toldo Jr \& Almeida (2009) recognize the Guaíba system as a river due to the presence of a main channel that presents strong water flows, a feature that would not be observed in lakes. 


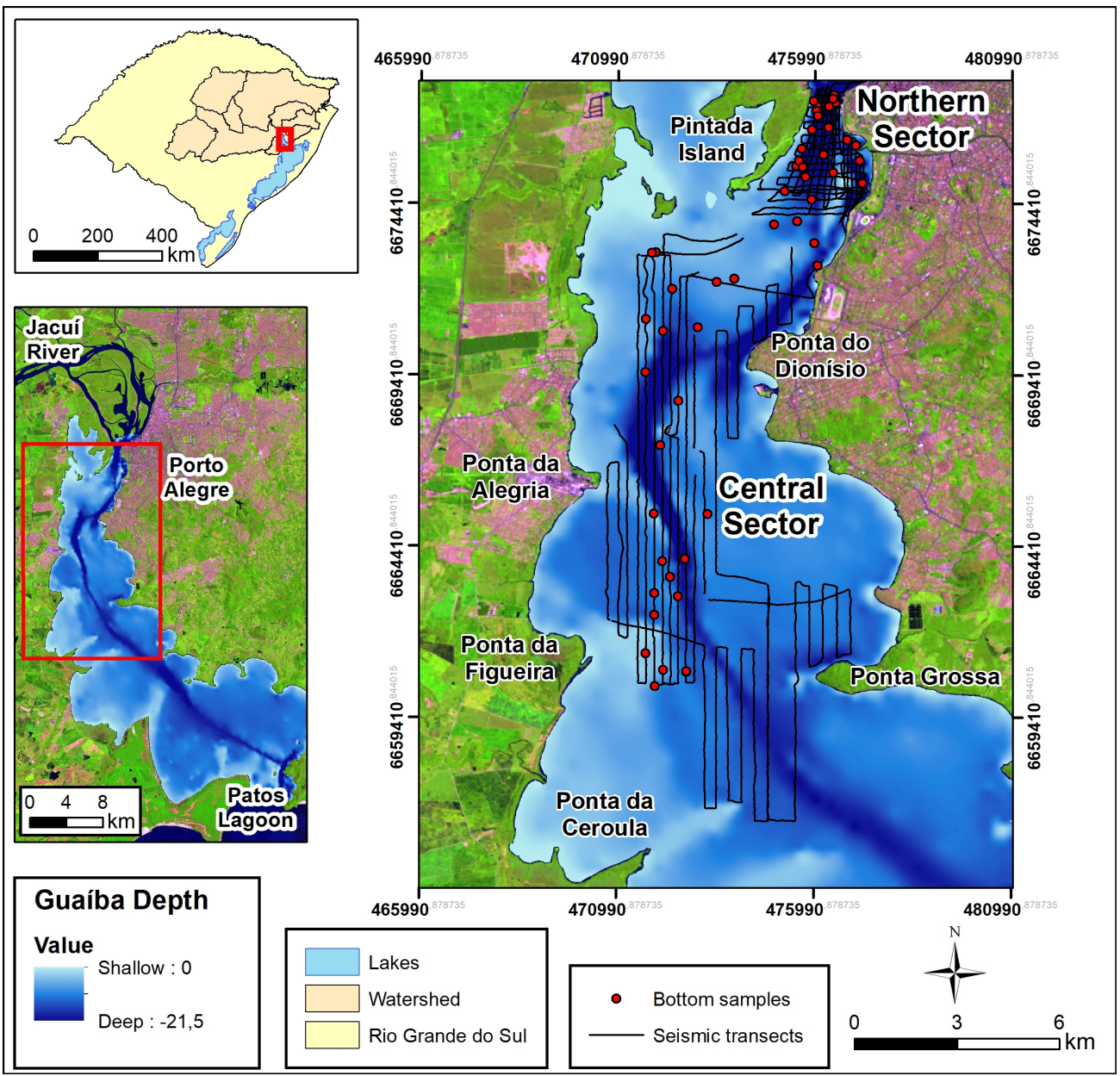

Figure 1 - Location of the study area. Seismic lines and collected bottom samples. The Northern Sector corresponds to the upstream end of the Guaíba River; the Central Sector represents the area from the south of Pintada Island until near Ponta da Ceroula. Landsat 8 image, OLI sensor, 6R5G4B composition. Coordinates in UTM, zone 22S.

Despite the strong anthropic pressure exerted on this water body, one factor to be highlighted is the lack of available data and published studies, which itself makes it difficult to classify it as a river or lake. Information on its bottom is found on the textural maps available in CECO (1999), which were developed using field sampling and allowed the analysis of this environment general behavior. Seismic studies using an acquisition grid with significant data and information on the bottom and sub-bottom have not been found.

\section{MATERIAL AND METHODS}

\section{Sampling and data collection in the field}

A total of $324 \mathrm{~km}$ of data transects (Fig. 1) were acquired with a 10 kHz Stratabox seismic profiler and concomitant bottom imaging using a 455 kHz Humminbird 798ci SI Side-Scan Sonar (SSS), both coupled to a Differential Global Positioning System (DGPS). For logistic reasons, this study focused on the Northern (NS) and Central (CS) sectors of the Guaíba River. Ten campaigns were carried out in the following periods and locations: January 2016 in the NS ( 3 days); June 2016 in the NS and CS ( 5 days); February 2017 in the CS (2 days).

Seismic data were sampled by navigating at speeds between 3 and 4 knots, allowing the generation of an adequate aspect ratio for the images (Paolo \& Mahiques, 2008). In order to aid the interpretation of seismic profiles, 42 bottom samples were preferentially collected on the acquired seismic transects (Fig. 1). A type of Van Veen bottom sampler was used, which does not allow the loss of fine sediments when it is being hoisted to the vessel (Carvalho et al., 2000). 
Data from seismic profilers sampled in previous years were also used to support the interpretation of the geoacoustic grid in some specific regions. The data corresponded to the following dates and equipment operating frequencies:

- Data acquired in 2006 at a $3.5 \mathrm{kHz}$ frequency in the navigation channel area (deeper areas);

- Data acquired in 2012 and 2014 with the same seismic profiler used in the mapping from this study $(10 \mathrm{kHz}$ Stratabox).

\section{Data analysis}

The main steps of this study were: granulometric analysis of bottom samples; interpretation and classification of seismic profiles; integration of data to produce maps with geoprocessing techniques; and finally, hydrodynamic and sedimentological interpretation.

The bottom samples were dry sieved at 0.5-phi intervals. The silt and clay fraction was separated from the rest with a 4-phi sieve. The bottom samples served as field truth for further interpretation of seismic transects.

The seismic profiler data were interpreted and classified using the SonarWiz, Reflexw, and Stratabox computer programs. The SSS data were used to support the interpretation of the seismic records acquired by the sub-bottom profiler. Different echo-characters were classified according to the sediment acoustic response, microtopography and morphology of the bottom and sub-bottom as proposed by Damuth (1980). The bathymetry data from Nicolodi (2007) was also used as a basis for the interpretation of echograms.

Seismic data were arranged into vector (line) data in geoprocessing applications. From there, maps with the classifications of echo-characters were made. Finally, the sedimentation and hydrodynamics of the Guaíba system were interpreted.

\section{Classification of subaqueous features}

The classification of large-scale features according to Ashley (1990) was used, which names and standardizes the bottom undulations as subaqueous dunes and categorizes them into sizes based on their spacing $(\mathrm{S})$ and height $(\mathrm{H})$ : very large dunes: $\mathrm{S}>100 \mathrm{~m}$, and $\mathrm{H}>5 \mathrm{~m}$; large dunes: $10 \leq \mathrm{S} \leq 100 \mathrm{~m}$, and 0.75 $\leq \mathrm{H} \leq 5 \mathrm{~m}$; medium dunes: $5 \leq \mathrm{S}<10 \mathrm{~m}$, and $0.4 \leq \mathrm{H}<0.75$ $\mathrm{m}$; small dunes: $0.6 \leq \mathrm{S}<5 \mathrm{~m}$, and $0.075 \leq \mathrm{H}<0.4 \mathrm{~m}$.

In addition to size and shape, Ashley (1990) also established a hierarchy with three orders of description on the main morphological characteristics of subaqueous dunes: first order: wavelength, height, and two (2D) or three (3D) dimensions; second order: size and orientation of overlapping features, and sediment characteristics (type and grain size); third order: facies angle and profile symmetry, area of bed coverage, and temporal evolution.

\section{RESULTS AND DISCUSSION}

\section{Echo-character types}

The echo-characters were classified based on the acoustic backscatter and bottom microtopography (Catanzaro et al., 2004), and were divided into seven different echo types named EC-1 to EC-7 (Tab. 1). The Northern (NS) and Central (CS) sectors of the Guaíba River, represented by Figures 2 and 3, respectively, were presented separately to facilitate the results visualization.

The main characteristic of echo 1 is that it has a low sub-bottom penetration and a predominantly flat terrain without any bottom features. This echo is mainly related to sandy sediments and is frequent in the Guaíba system (Figs. 2 and 3).

Echo 2 has bottom features, strong reflectivity, and low sub-bottom penetration. Its occurrence is concentrated at the upstream end of the Guaíba River and more sporadically in areas near the main channel (Figs. 2 and 3). The behavior of these two types of echo-characters - with strong reflection and low penetration - is similar to other studies in different areas of Brazil (Catanzaro et al., 2004; Paolo \& Mahiques, 2008; Veronez Jr et al., 2009a; Baptista Neto et al., 2011; Silva et al., 2014).

Echo 3 presents abrupt and sporadic relief variations. It is similar to echo 1 regarding its strong reflection, but they differ with respect to the abrupt relief variation of echo 3. This type of echo is concentrated in the eastern areas from the NS, close to the Dilúvio Stream and the Beira Rio Stadium (Fig. 2).

Echo 4 is formed by discontinuous and chaotic reflectors and occupies widely varied elevations above the bottom, ranging from 6 to $14 \mathrm{~m}$ deep. This echo has high reflectivity and no penetration in most profiles. Sometimes its sound signal penetrates in the first reflector, evidencing a highly reflective and irregular sub-bottom surface. This echo is concentrated in the NS (Fig. 2) and CS at the upstream end of the Guaíba River and in the areas near Ponta do Dionísio and Ponta Grossa (Fig. 3), respectively. Echoes 3 and 4 are related to the presence of irregular bathymetry areas on the Guaíba River bottom.

Echo 5 presents sub-bottom reflectors located in the NS at the upstream end of the Guaíba River (Fig. 2). The bottom morphology is dominantly flat on this echo and sometimes 
Table 1 - Types of classified echo-characters in the Guaíba River.

\begin{tabular}{|c|c|c|c|c|}
\hline Echo & Description & Sediment & Occurrence & Profile \\
\hline EC-1 & $\begin{array}{c}\text { Highly reflective } \\
\text { surface, low penetration. } \\
\text { Without bed forms. }\end{array}$ & Sand & Predominant in the CS. & \\
\hline EC-2 & $\begin{array}{l}\text { Highly reflective } \\
\text { surface, low penetration. } \\
\text { With bed forms. }\end{array}$ & Sand & $\begin{array}{l}\text { Upstream end of the Guaíba River } \\
\text { and channel areas. }\end{array}$ & 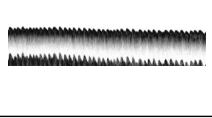 \\
\hline EC-3 & $\begin{array}{c}\text { Highly reflective } \\
\text { surface, low penetration. } \\
\text { Abrupt relief variations. }\end{array}$ & Sand & $\begin{array}{l}\text { Areas at the eastern margin. } \\
\text { Only Northern Sector. }\end{array}$ & \\
\hline EC-4 & $\begin{array}{l}\text { Basement highs } \\
\text { or outcrops. }\end{array}$ & - & $\begin{array}{l}\text { Upstream end of the Guaíba River } \\
\text { and near rocky basement areas. }\end{array}$ & \\
\hline EC-5 & $\begin{array}{l}\text { High penetration. } \\
\text { Presence of several } \\
\text { reflectors and one strong } \\
\text { sub-bottom reflector. }\end{array}$ & Mud & $\begin{array}{l}\text { Guaíba entrance. } \\
\text { Only Northern Sector. }\end{array}$ & 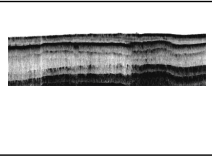 \\
\hline EC-6 & $\begin{array}{l}\text { High penetration. } \\
\text { Presence of } \\
\text { sub-bottom reflectors. }\end{array}$ & Mud & Varied only in CS. & - \\
\hline EC-7 & $\begin{array}{l}\text { High penetration. } \\
\text { Presence of regular } \\
\text { sub-bottom reflector. }\end{array}$ & Sand & $\begin{array}{l}\text { Sandy areas in } \\
\text { Ponta da Figueira. }\end{array}$ & 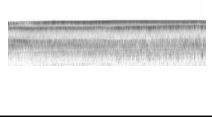 \\
\hline
\end{tabular}

presents irregular bottom shapes in the form of single ripples that may have migrated from nearby subaqueous dune areas (echo 2). This echo has several sub-bottom reflectors and presents a well-defined, flat, and high-amplitude one. While the other sub-bottom reflectors do not continuously appear in any area, this strong reflector was recorded over the entire extent of the echo 5 occurrence.

Echo 6 indicates a flat-bottom relief in most profiles and one or more sub-bottom reflectors located in several portions from the CS predominantly in the channel or deeper areas (Fig. 3). This echo was classified into three subtypes according to the sub-bottom reflector response (subtypes shown in Figure 11 and detailed later in the discussion). Echoes 5 and 6 have a better penetration of the acoustic signal and resolution of the sub-bottom reflectors. Echo 7 has a flat and regular reflector on the sub-bottom. This type is located near Ponta da Figueira, in the western Guaíba River area.

Previous studies have highlighted that SSS images do not allow the separation of echo-characters with the same degree of detail as a seismic profiler (Paolo \& Mahiques, 2008; Veronez Jr et al., 2009a). Many features were not adequately recorded by the
SSS and were indirectly interpreted by the variation of the water column (in the center of the image) in the sonographic records, similar to what was commented by Paolo \& Mahiques (2008). One of the factors that made it difficult to acquire and interpret the SSS data was the shallow depths of the Guaíba system, which have an average of $2 \mathrm{~m}$ deep. In the shallower regions, SSS images had only a few meters of imaging extension ( $<10 \mathrm{~m}$ long).

\section{HYDRODYNAMIC AND SEDIMENTOLOGICAL INTERPRETATIONS BASED ON SEISMIC ANALYSES}

\section{Echo 2 and the mapping of subaqueous dunes}

In the NS, the presence of subaqueous dunes (Echo 2) was recorded in the western portion of the studied area, parallel to Pintada Island, as well as in the shallower portions to the east of the navigation channel (Fig. 2). These dunes were asymmetrical, indicating a predominant flow in the north-to-south direction. The area to the east of the navigation channel presented small and medium dunes predominantly with medium sand grains. This variation occurred due to the shallow depths in referred site, ranging from 1 to $4 \mathrm{~m}$. 


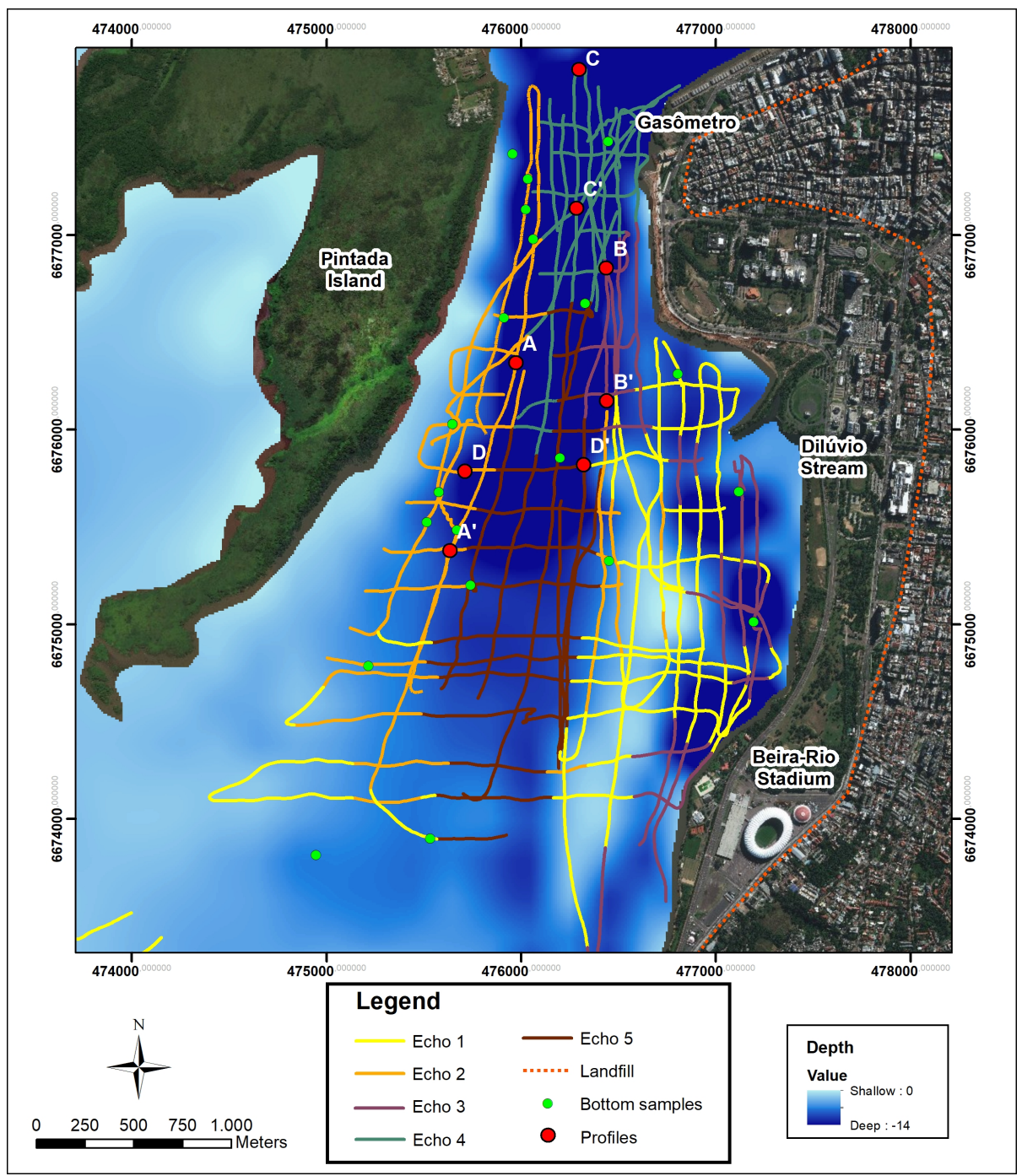

Figure 2 - Classification of echo-characters from the NS of the Guaíba River. The landfill areas were manually delimited based on the map by Hasenack (2008). Coordinates in UTM, zone 22S.

In the areas with subaqueous dunes in the western portion, a large north-to-south variation in the size of features was verified (Fig. 4), with very large dunes in the north end that gradually varied to medium and small dunes in the southern border of the study area. Variations in wavelength were also observed as a function of depth. Smaller dunes were concentrated in shallower regions, closer to the western margin, and larger dunes were found at greater depths farther from the shore. The presence of dunes and their size gradient was also confirmed in the profiles from 2006, 2012, and 2014.

The bottom samples showed more than $90 \%$ of sand in the areas with subaqueous dunes, as also observed in different environments in the literature (Fenster et al., 1990). However, the changes in the size of dunes were followed by a variation in the grain size of the sandy sediments that constituted them. The sediments with larger grain size - mainly the coarse sand fraction - and the medium to very fine sand fractions were concentrated in the north at the upstream end of the Guaiba River and in the southern portions, respectively.

In the CS, in the areas near the navigation channel close to Ponta do Dionísio, small and medium dunes were also mapped at 2.5 to $7 \mathrm{~m}$ deep (Fig. 3). In other regions to the south until Ponta da Ceroula and Ponta Grossa, no subaqueous dunes were found. The presence of subaqueous dunes in the channel 


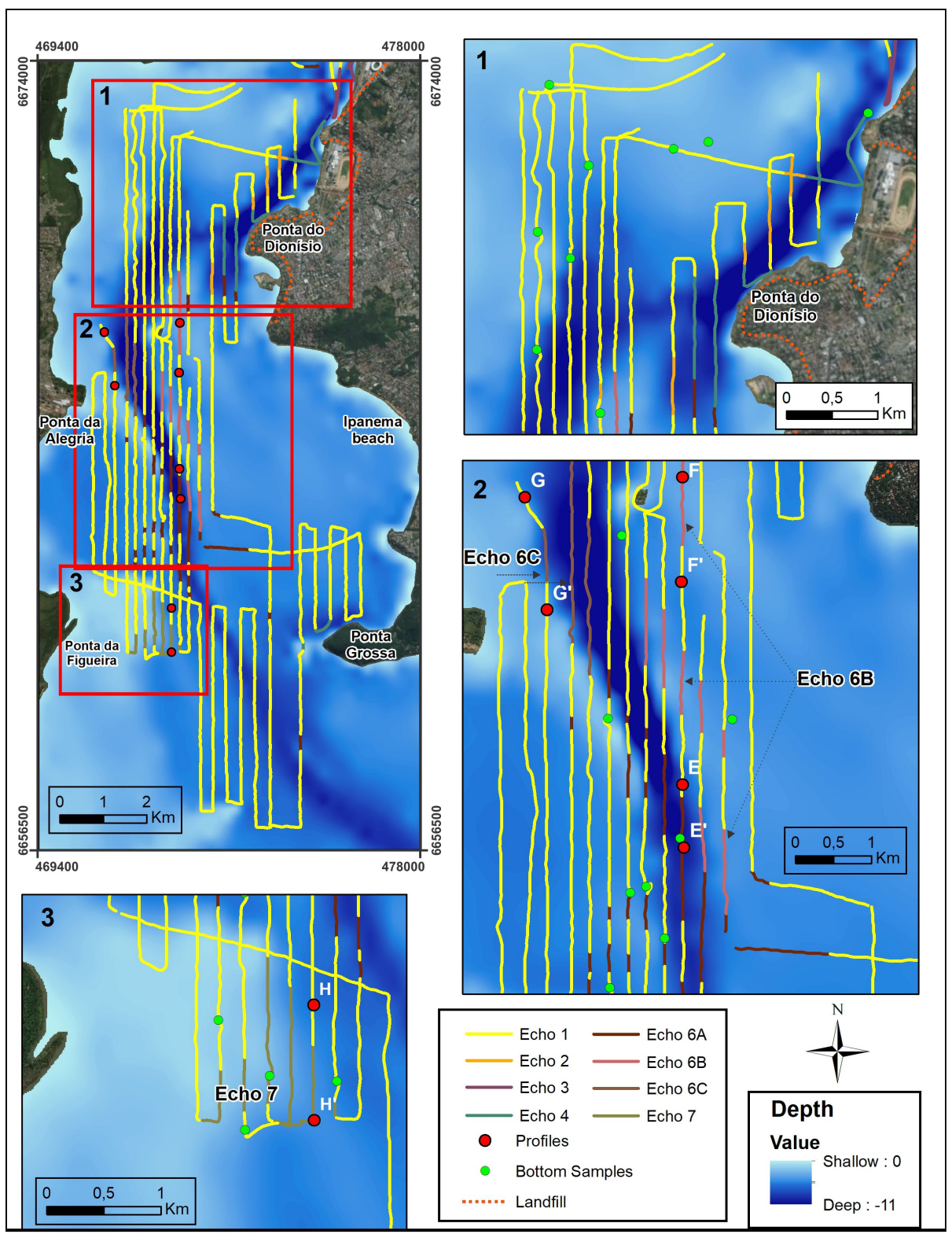

Figure 3 - Classification of the echo-characters from the CS of the Guaíba River. The landfill areas were manually delimited based on the map by Hasenack (2008). Coordinates in UTM, zone 22S.

area indicated higher flow velocities and gave evidence of a predominant north-to-south flow due to their asymmetry, which was constant along the seismic profiles.

The decrease in the size of ripples until their total absence showed that the flow competence decreased towards the south. The Guaíba River cross-section is initially about $0.8 \mathrm{~km}$ wide at Gasômetro and gets wider towards the south, reaching $4.3 \mathrm{~km}$ and $5.9 \mathrm{~km}$ wide in the sections at Ponta do Dionísio and Ponta Grossa, respectively (Fig. 3). This widening coincided with the
Ioss of transport competence of thicker sediments observed with the seismic profiles and the bottom samples, which showed a decrease of the sand grain size deposited on the bottom. This behavior was previously reported by other authors (Bacchi et al., 2000; Nicolodi, 2007), who observed that the river flow from the tributaries loses competence as a transport agent when draining into the Guaíba River.

The conditions required for the formation of subaqueous dunes according to Ashley (1990) are: environments deeper than 


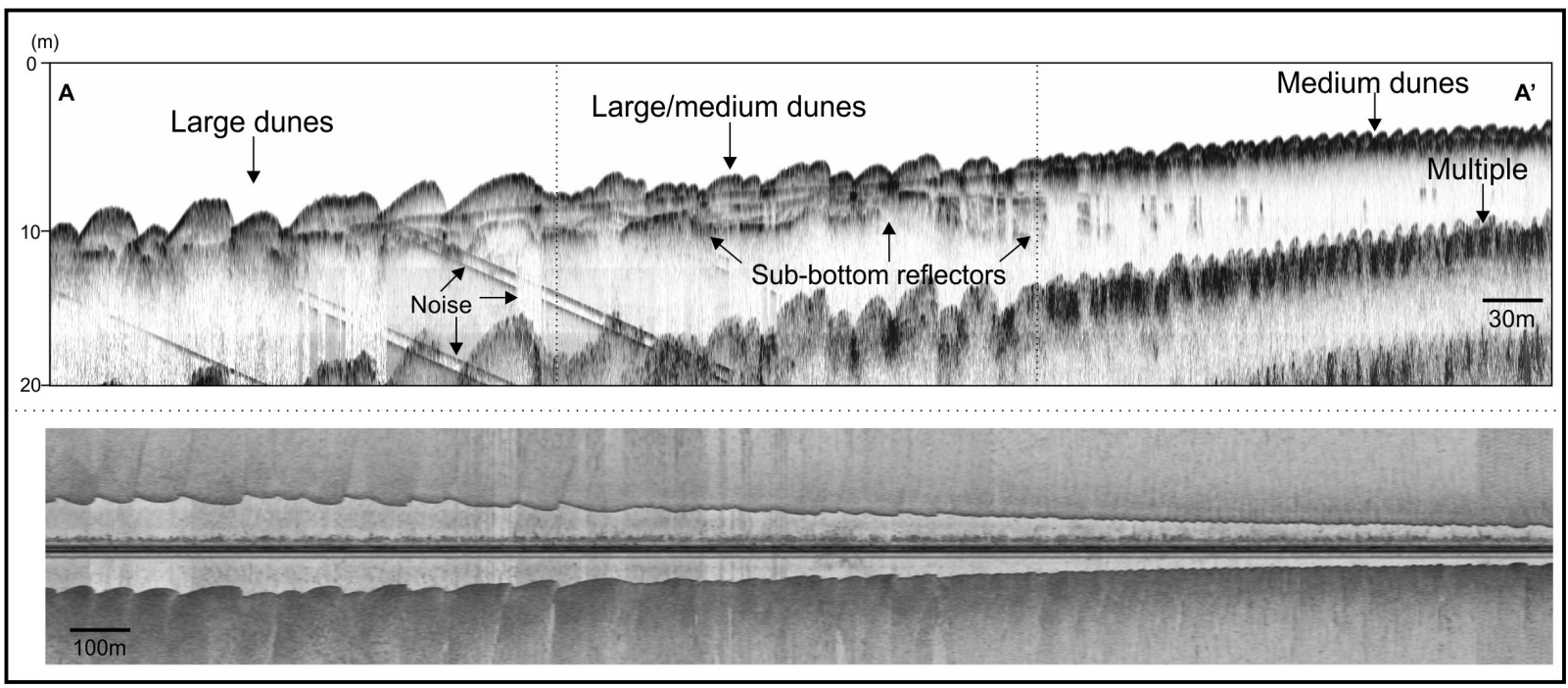

Figure 4 - Echo-character type 5. Subaqueous dunes profile in the NS from the Guaíba system. Top - acoustic profiler Stratabox. Bottom - SSS. Modified from Silva Jr (2017).

$1 \mathrm{~m}$; grain size greater than very fine sand $(>0.15 \mathrm{~mm})$; and velocity of currents greater than 0.4 m.s. ${ }^{-1}$. The first and second conditions were met and confirmed by the use of the bathymetry and bottom samples, respectively. The higher velocities in the northern area were confirmed in the study by Andrade et al. (2017), who used a Doppler current acoustic profiler to measure currents at Ponta do Gasômetro in the Northern Sector of the Guaíba River (Fig. 5). In an example profile from September 15, 2015, the highest velocities, which were over $40 \mathrm{~cm} \cdot \mathrm{s}^{-1}(0.4$ $\left.\mathrm{m} . \mathrm{s}^{-1}\right)$, occurred in the western area of the section, exactly where the dunes were located.

Subaqueous dunes were also mapped at the Guaíba River mouth in Itapuã (Fig. 6) using data measured by a $3.5 \mathrm{kHz}$ seismic profiler in July 2006. These ripples were the size of medium dunes and presented asymmetry, indicating that the flow was predominantly from north to south. These bottom features are common in zones of intense current velocities and were previously described by Baitelli (2012). The longitudinal section of Itapuã is a few kilometers long - ranging from 3.6 to $5 \mathrm{~km}$-, similarly to the section of Dionísio (Fig. 3), which is $4.3 \mathrm{~km}$ long. The narrowing of the section causes an increase in the current velocities in the flow channel area, producing the subaqueous ripples.

The presence of subaqueous ripples indicated that the flow reached the entire water column in these areas and did not only occur superficially as proposed by Menegat \& Carraro (2009). This condition is also highlighted in Figure 5, where intense velocities were evident at depths greater than $10 \mathrm{~m}$ and near the channel bottom.

The asymmetry of the subaqueous dunes confirmed that the flow in the Guaíba River is preferentially from north to south (DNAEE, 1983; Nicolodi, 2007; CHM, 2012), corroborating that the Guaíba system has a predominant river behavior. According to Ashley (1990), the formation of subaqueous dunes only takes place in three environments: rivers, tide-dominated coastal environments, and shallow marine environments. Since it is not a marine environment and has no tidal effect, the Guaíba system falls into the classification of a river.

\section{Echo 3}

Echo 3 occurred throughout the eastern area of the NS at the margins of the city of Porto Alegre (Fig. 2). Irregularities and abrupt relief variations indicated dredging and dredged material disposal (Fig. 7). Baptista Neto et al. (2011) also defined a similar echo using data from a similar equipment (10 kHz Stratabox) in Rodrigo de Freitas Lagoon, city of Rio de Janeiro, Brazil, and they associated it to dredging in the area.

The occurrence of echo 3 was related to the occupation history of the city, which has undergone seven landfill processes in its margin (Bohrer, 2001). The first landfill took place in the 19th century in 1888 aiming at expanding and modernizing its port area (Branco Filho, 2005). This operation continued in the 20th century to implement the other six landfills, finished between 1917 and 1978. According to Branco Filho (2005), the Praia de 


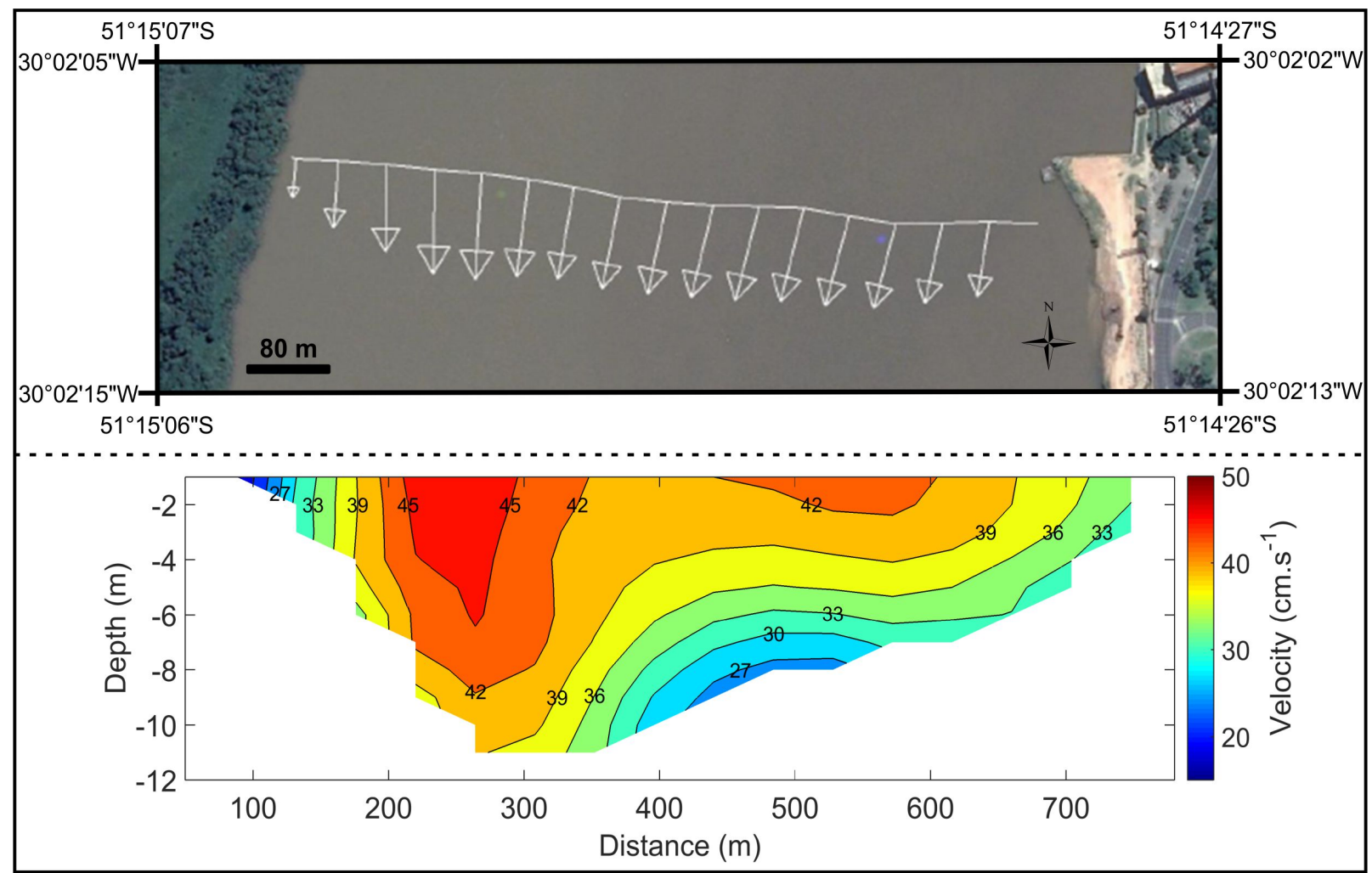

Figure 5 - Cross-section at Gasômetro. Top panel - velocity vectors from the surface layer. Bottom panel - side view of the cross-section. Source: Andrade et al. (2017).

Belas beach (next to Beira Rio Stadium) landfills in the 1970s were made with sediments from the Guaíba River, which were removed by dredging and using large pipes. On the other hand, regarding the other previously made landfills, there is no record on the methodology used.

Changes in the bottom morphology and depths can be observed comparing the 1960s nautical chart from the Brazilian Navy with the actual bathymetric map of this study (Fig. 8). According to the nautical chart this region had depths ranging from 0.1 to $1.4 \mathrm{~m}$ prior to the construction of the landfill, which are shallower than the current configuration of these areas with depth locally greater than $10 \mathrm{~m}$.

\section{Echo 4}

Echo 4 was characterized by discontinuous and chaotic reflectors and a highly irregular and reflective bottom (Fig. 9). This echo-character was located close to the margins of Ponta do Gasômetro (Fig. 2), Ponta do Dionísio, and Ponta Grossa (Fig. 3), which are areas that present granitic rocks (Hasenack, 2008). These echo characteristics are associated with rock outcrops, which are the extension of nearby basement.
These echo-character has also been described with similar characteristics in other works, which have associated it with rock outcrops and rock blocks (Catanzaro et al., 2004; Veronez Jr et al., 2009a), showing a strong reflectivity due to the high intensity of its acoustic return signal (Veronez Jr et al., 2009a).

On the other hand, the Ponta do Gasômetro area is a landfill area that served as foundation to build a prison, which was destroyed in the 1960s and left debris that are still present at the Guaíba margins. In this specific area, the disposal of these remains is also a possible explanation for the echo-facies pattern observed in this study.

\section{Echoes 5 and 6, and deposition of fine sediments}

Echo-characters 5 and 6 showed more-pronounced sub-bottom reflectors and were related to the presence of fine sediments on the bottom and shallow sub-bottom. The bottom samples resulted in the predominance of fine sediments (65-99\%) in these areas.

Echo 5 occurred in the NS of the Guaiba River aligned with the Dilúvio Stream mouth, which is where the Guaíba River practically doubles its cross-section width (Fig. 2). Veronez Jr et al. (2009a) also reported a similar echo using $10 \mathrm{kHz}$ seismic 


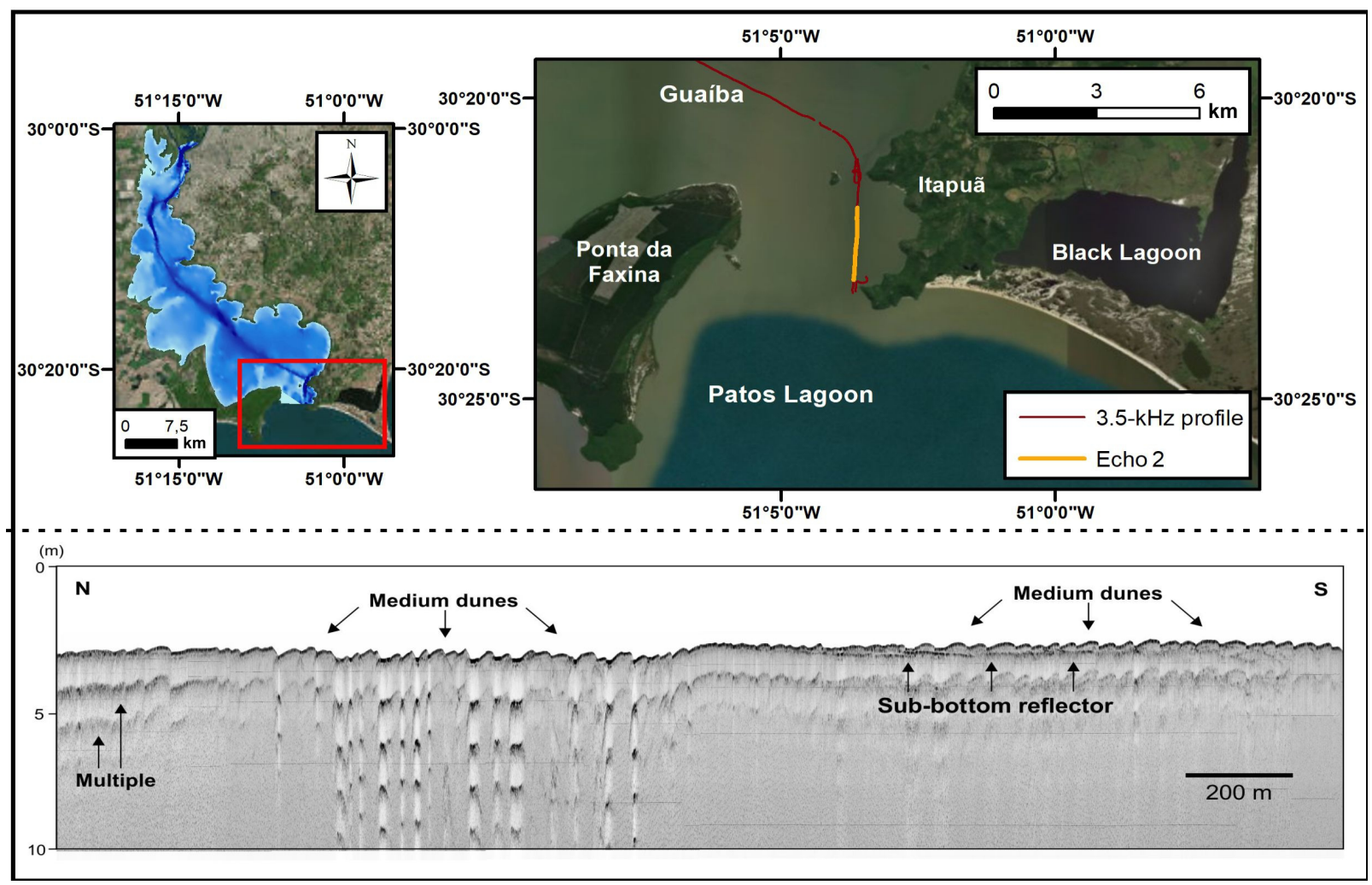

Figure 6 - Location and seismic profile (3.5 kHz) of subaqueous dunes mapped at the Guaiba River mouth in Itapuã. The north and south orientations are indicated in the profile.

(m)

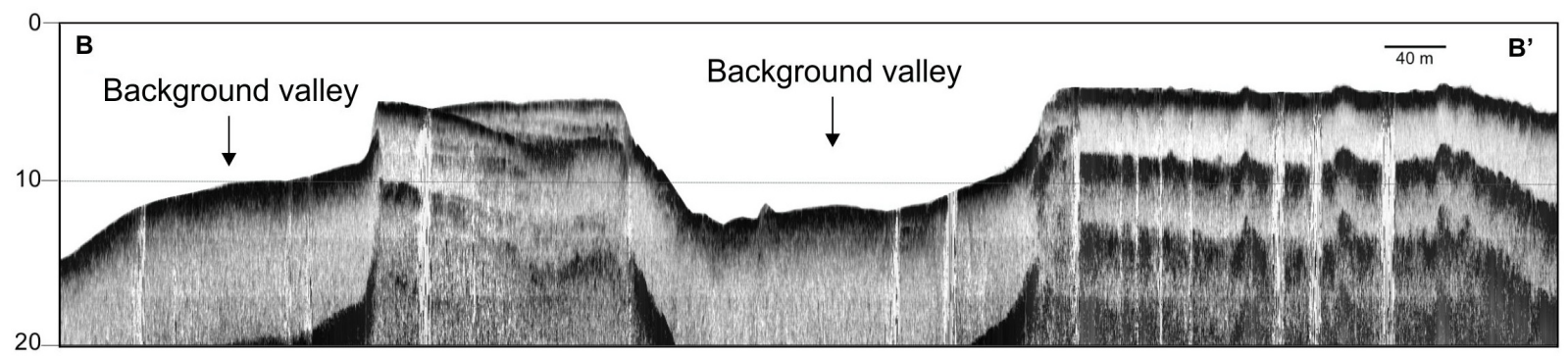

Figure 7 - Echogram associated with echo 3. Presence of large troughs on the bed and dredging disposals between the troughs. Modified from Silva Jr (2017).

profiling data from Vitória Bay and associated it with the mud or muddy-sand bottom.

These echograms showed thick tabular layers formed by the deposition of fine sediments and presented concordant reflectors on the sub-bottom (Fig. 10). It is possible to visualize several sub-bottom reflectors, but there was one presenting a high-amplitude (Fig. 10, Reflector R3) and a weaker deeper one (low-amplitude), not being present throughout the profile.

The high-amplitude sub-bottom reflector (R3) was identified throughout the echo 5 occurrence area, which was a characteristic that defined this echo-character. At the sites adjacent to the channel margins, these echoes showed isolated sandy bars close to the formation of the echo 2 subaqueous dunes. These bars represented an intermediate phase between these sectors of high and low flow speed.

It is also noted that the echo 5 location was associated with the navigation channel and that it was found in its deeper portions, with depths varying from 5 to $14 \mathrm{~m}$ (Fig. 2). In probable conditions of low flows, the loss of competence favors the deposition of finer sediments. Nicolodi et al. (2010) defined three 


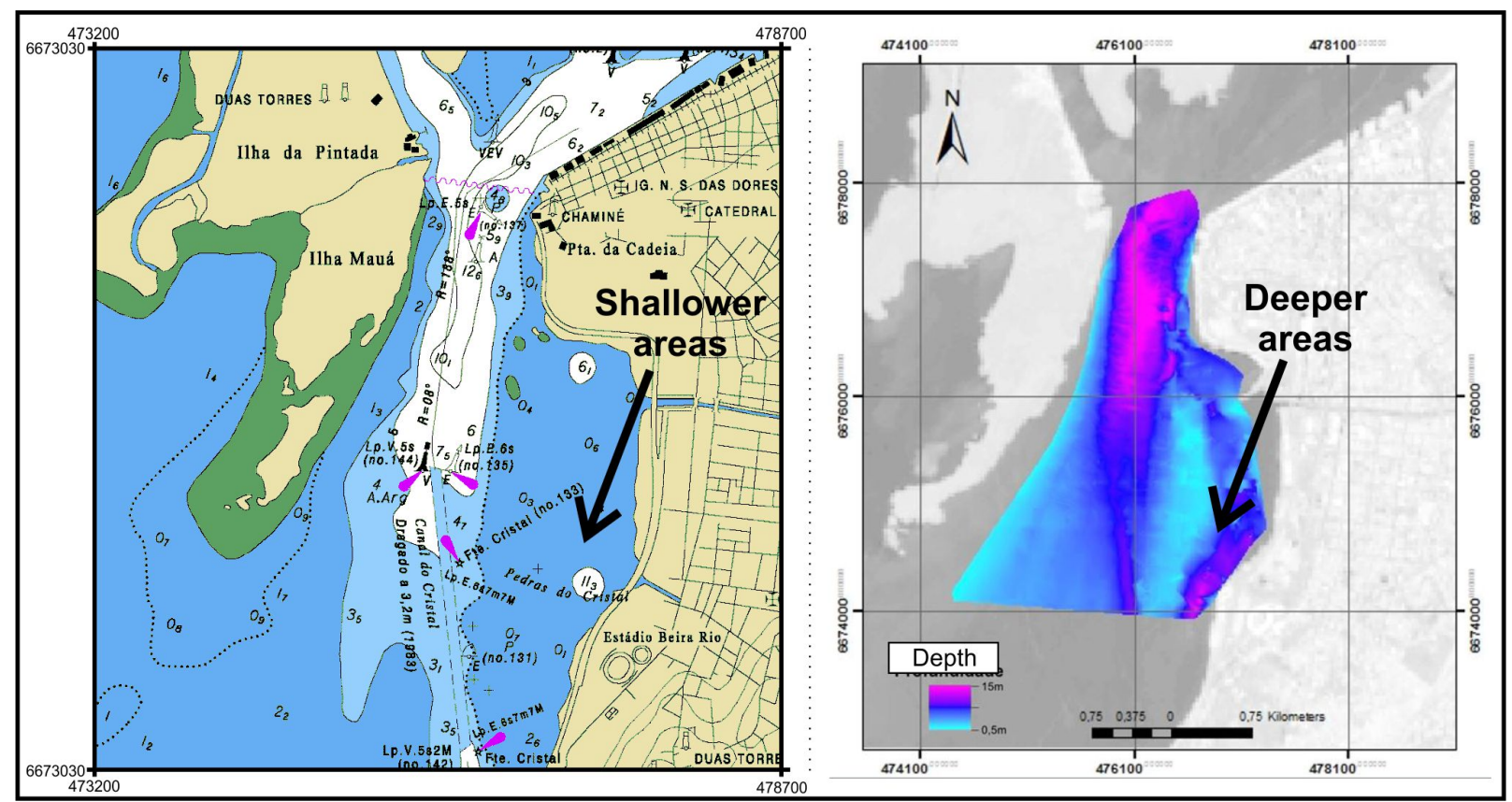

Figure 8 - Comparison between the 1960s Brazilian Navy nautical chart (CHM, 2012) and the bathymetric map from this work. The bathymetric map on the right was performed with seismic profiler data. Coordinates in UTM, zone 22S. Modified from Silva Jr (2017).

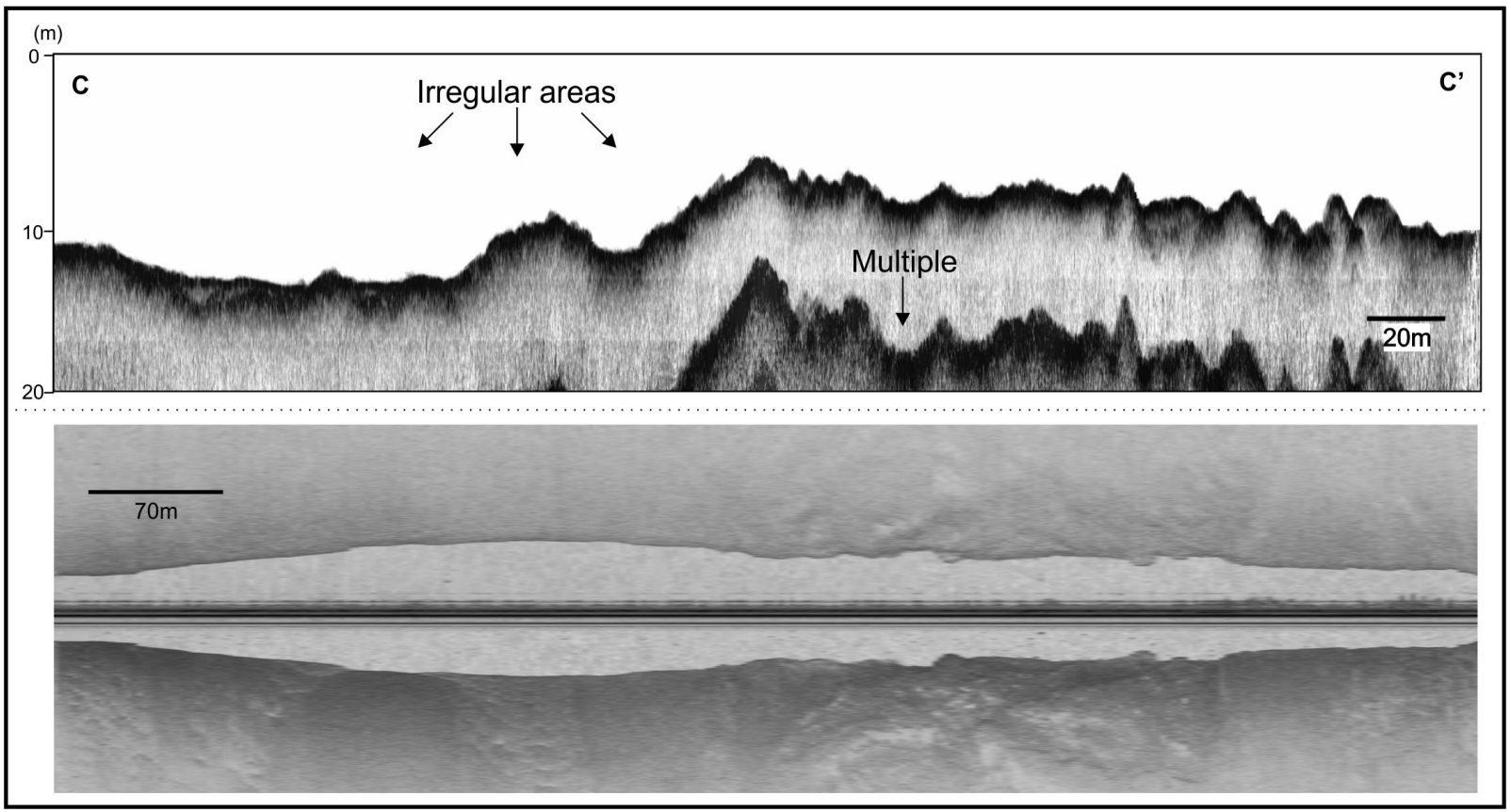

Figure 9 - Profile showing the echo type 4. Top - acoustic profiler Stratabox. Bottom - SSS. Modified from Silva Jr (2017).

different sedimentary environments according to the potential for fine sediment resuspension in the Guaíba River: erosional, transitional, and depositional bottoms. The depositional bottom corresponds to areas with fine sediment deposition, characteristic of regions that are protected from the main resuspension forces and that have low hydrodynamic energy (Nicolodi et al., 2013). 


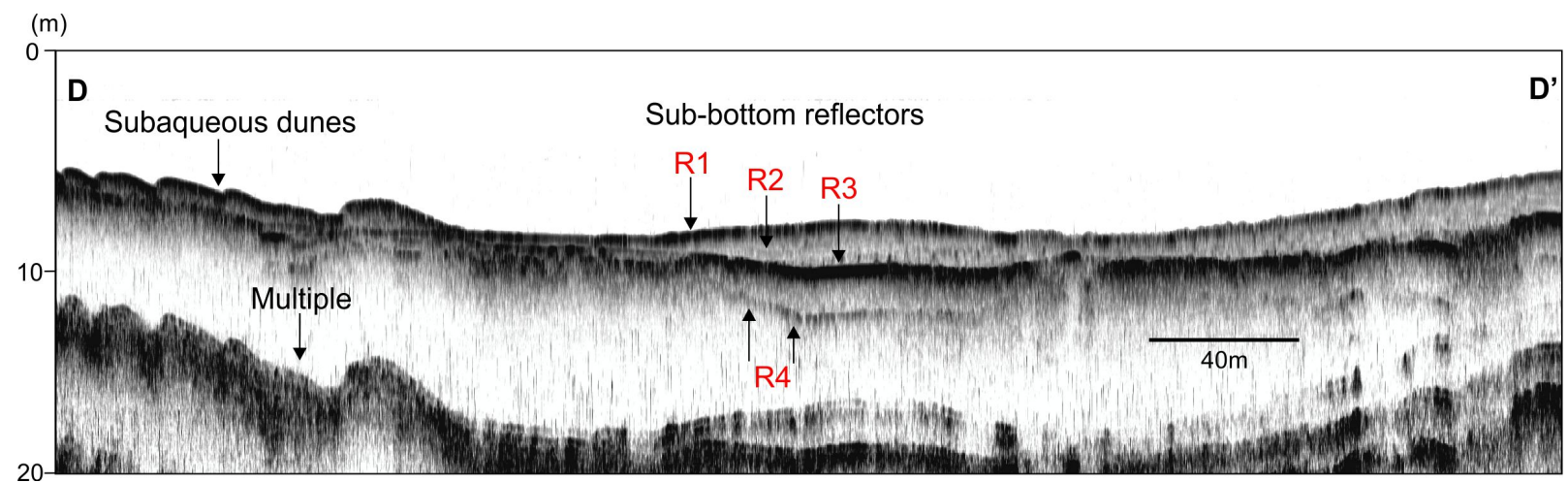

Figure 10 - Echo-character type 5 and sub-bottom strata. Modified from Silva Jr (2017).

These areas showed great spatial similarity with the areas classified as echo 5 and confirmed the dominance of a fine sediment depositional area in the NS of the Guaiba River.

The coastal fluvial courses from the Guaiba watershed maintained their positions relatively fixed during the Quaternary period. The sub-bottom morphology that showed strong amplitude of the echo 5 reflector can be interpreted as the position of the paleochannel bed of the former Jacuí River course, which dissected the entire length of the Guaiba River basin until it met PL (Weschenfelder et al., 2010, 2014). This paleochannel had the same position of the current navigation channel from the Guaíba River, thus being a morphological inheritance of the relief dissection during periods of lower base level, drowned by the high and transgressive sea from the end of Holocene (Weschenfelder et al., 2016; Santos-Fischer et al., 2016, 2018).

Echo 6 occurred in the CS in the channel and in other predominantly deeper areas, ranging from 2.5 to $11 \mathrm{~m}$ deep. The quantity and arrangement of reflectors was varied and did not present a uniform pattern. Thus, this echo was divided into 3 subtypes shown in Figure 11. Echo 6A showed a pattern of various sub-bottom strata, which were concordant in most profiles. Eventually, the presence of a high-amplitude sub-bottom reflector was exclusively identified in the channel areas, also interpreted as the position of the Jacuí River paleochannel bed (Fig. 11). This reflector resembled the characteristics of echo 5, which presented a high-amplitude sub-bottom reflector throughout its extension.

Echo $6 \mathrm{~B}$ was located in an area to the east of the channel in shallower depths, between 2.5 and $4.5 \mathrm{~m}$ deep (Fig. 3). This echo subtype presented an irregular sub-bottom reflector at approximately $1 \mathrm{~m}$ under the bottom reflector located to the east of the navigation channel. Echo $6 \mathrm{C}$ sporadically occurred in the channel area near Ponta da Alegria (Fig. 3) between 4.5 and $7.5 \mathrm{~m}$ deep. The characteristic that defined this echo was the bed irregularity in a sub-bottom reflector (Fig. 11) and the eventual presence of others. The echo 6 areas were associated with the muddy sediment present in the bottom.

The deposition of fine sediments was recorded by the bottom samples in deeper areas, the navigation channel and surrounding areas. This result, in general, is in agreement with the work by Bacchi et al. (2000), which reported the presence of fine sediments under the 3-m isobath. Despite that, some deeper regions close to the channel were classified as echo 1 areas. This echo can be observed in the CS in transects that covered the northern and southern areas (Fig. 3), which must have more-consolidated muds due to the echo 1 strong reflectivity.

\section{Echo 7}

Echo 7 showed a concordant flat sub-bottom reflector (Fig. 12) and was locally mapped at Ponta da Figueira (Fig. 3), a shallow area (1 to $3 \mathrm{~m}$ deep) with sandy bottom. The bottom samples presented over $64 \%$ of sand with a predominance of medium sand. The thickness between the bottom and sub-bottom reflectors ranged from 0.4 to $1.1 \mathrm{~m}$.

This type of echo was not found in the shallowest areas of Ponta da Figueira - between 0.6 and $1 \mathrm{~m}$ deep, but it occurred to the south and southwest of these regions. It also occurred parallel to the navigation channel at approximately $750 \mathrm{~m}$ from it. The echo-character 7 was associated with the reworking of submerged sandy sediments parallel to Ponta da Figueira. Its inclination was similar to the main orientation of the navigation channel in that area, which is towards the southwest. 


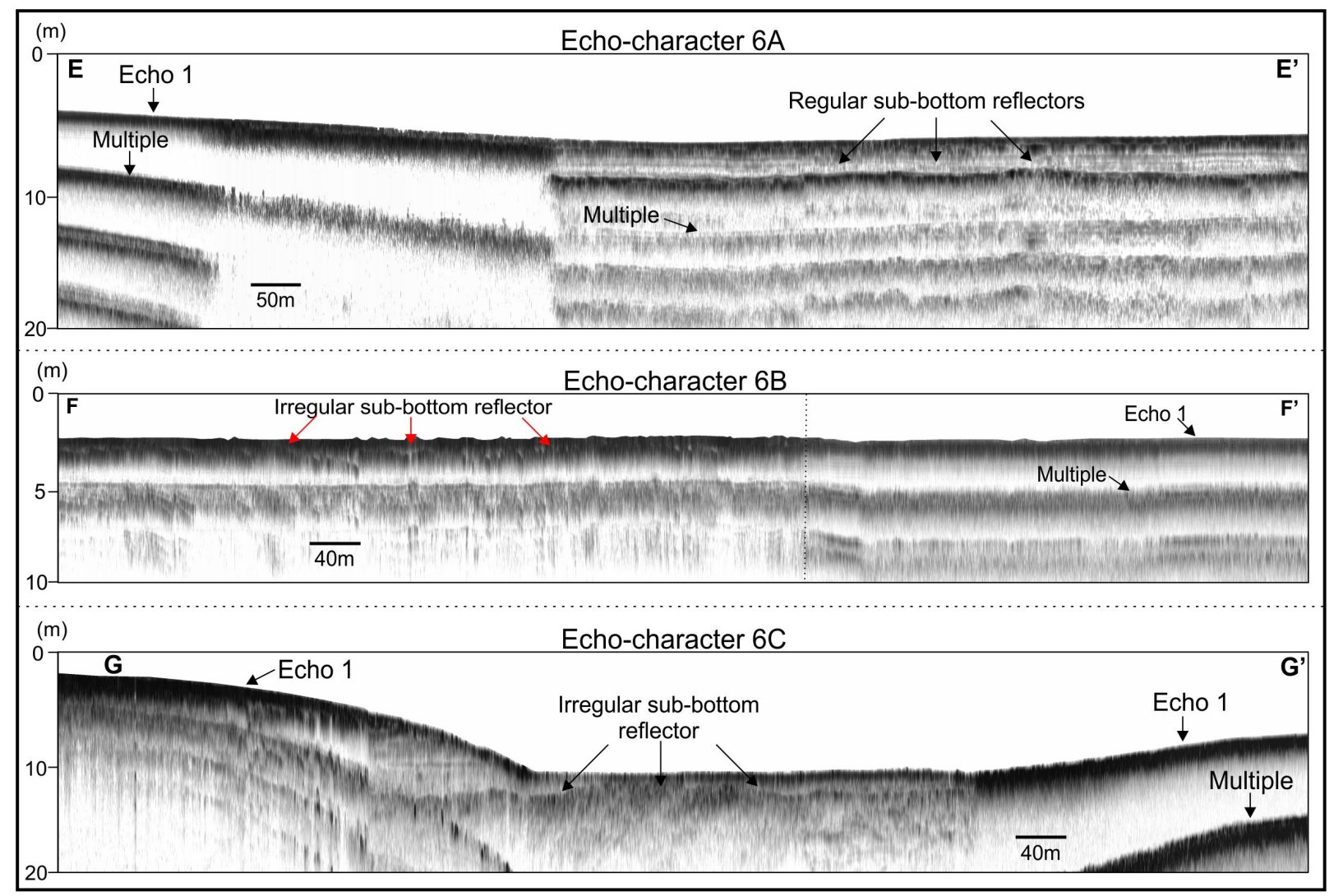

Figure 11 - Echo-character type 6 and its variations (6A, 6B, and 6C) in the CS of the Guaíba River.

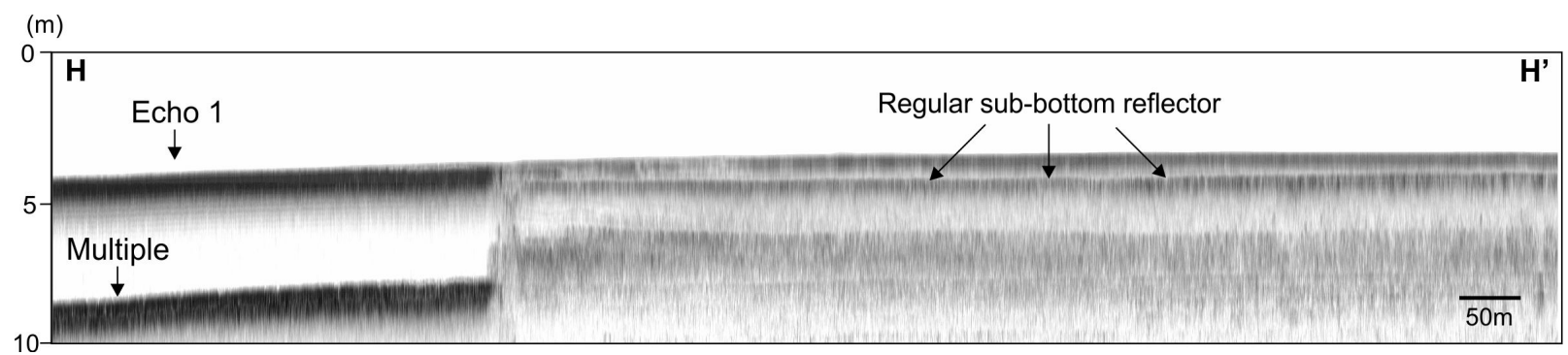

Figure 12 - Echogram associated with echo 7. Presence of flat relief and concordant reflectors on the right. Echo 1 area is shown on the left.

\section{Morphological, hydrodynamic, and evolutionary patterns of the Guaíba River}

In general, the echoes associated with the deposition of fine sediments occurred in deeper areas, the navigation channel or surrounding areas. The echoes in the shallower areas presented strong acoustic reflectivity at the sites with lower deposition of fine sediments and predominance of sandy sediments. The deposition of fine sediments was confirmed in the deeper areas with bottom samples. This result, in general, is in agreement with the work by Bacchi et al. (2000), which reported the presence of fine sediments under the 3-m isobath.

The Guaíba River flow, predominant in the north-to-south direction, presented interaction with the bottom and modification of bed forms, indicating that the flow was towards the south. The occurrence of subaqueous dunes in the Guaíba upstream end and river mouth corresponded to higher current flows in these areas. This factor indicates different types of environments that are 
mainly influenced by the longitudinal section. Narrower sections lead to higher current velocities and a greater system competence regarding sediment transport. The central areas from the Guaíba River did not present subaqueous dunes, thus showing a lower transport competence. Therefore, they had lower hydrodynamic energy when compared to the upstream end and river mouth areas from this system.

The predominant north-to-south direction of the flow with currents reaching the entire water column suggests that the Guaíba system has a slope in the channel, a requirement that defines a river channel. These factors allowed us to conclude that this system has a predominant river behavior: the Guaíba River.

The progressive decrease in the current speeds in the transition from the Northern and Central sectors causing the reduction of sediment transport competence. This decrease suggests that the sand is minimal or non-existent in the Central area of Guaíba. According to Scottá et al. (submitted), the areas outside the navigation channel have velocities that are not sufficient for the sandy sediment erosion and transport under normal net river discharge conditions. Only flood conditions with high net river discharges are sufficient for the sandy sediment erosion to take place, which occur sporadically.

The high-amplitude sub-bottom reflectors of echoes 5 and $6 \mathrm{~A}$ pointed to the position of the Jacuí River paleochannel bed, preserved in the areas of the Guaíba River navigation channel. Echoes $6 \mathrm{~B}, 6 \mathrm{C}$, and 7 - recorded near the navigation channel and parallel to it - indicated possible locations of the Jacuí River flood plain.

\section{CONCLUSION}

The sampled data, which included high-resolution $(10 \mathrm{kHz})$ seismic profiles, side-scan sonar imaging, and geological sampling, allowed to advance and update the knowledge of the microtopography and of the geological and hydrodynamic processes in the Guaiba River. The approach focusing on seismic methods gave the support to recognize and map - in a pioneer way - the areas of occurrence of subaqueous dunes and the seismic-depositional architectural elements of the Guaíba River.

It was possible to identify, analyze, and map the sedimentary distribution of the Guaíba River bottom and sub-bottom from geoacoustic data. Fine sediments were present in deeper areas along the navigation channel or adjacent areas, which are regions of fine sediment deposition when under lower hydrodynamic energy. The occurrence and morphology of asymmetric subaqueous dunes indicated a predominant north-to-south flow and a river behavior.

\section{ACKNOWLEDGEMENTS}

The authors thank the CNPq and CAPES for the PhD scholarship. The authors would like to thank the other postgraduate students from PPGGEO/UFRGS who assisted in the conducted campaigns and the CECO/UFRGS for providing the infrastructure for data sampling and processing.

\section{REFERENCES}

ANDRADE MM, SCOTTÁ FC, TOLDO Jr EE, WESCHENFELDER J \& NUNES JC. 2017. Hidrodinâmica do Rio Guaíba: resultados preliminares. In: XXII Simpósio Brasileiro de Recursos Hídricos. 2017, Proceedings... Florianópolis, Brazil. ABRH, 2017.

ASHLEY GM. 1990. Classification of large-scale subaqueous bedforms: a new look at an old problem. J. Sediment. Petrol., 60(1): 160-172.

BACCHI FA, BARBOZA EG \& TOLDO Jr EE. 2000. Estudo da sedimentação do Guaíba. Ecos, 17: 32-35.

BAITELLI R. 2012. Evolução Paleogeográfica do Sistema de Paleodrenagem do Rio Jacuí na Planície Costeira do Rio Grande do Sul. Doctorate Thesis, Programa de Pós-graduação em Geociências, Instituto de Geociências, Universidade Federal do Rio Grande do Sul, Brazil. 149 pp.

BAPTISTA NETO JA, SILVA MAM \& FIGUEIREDO Jr AG. 1996. Sísmica de alta frequência e o padrão de distribuição de sedimentos na Enseada de Jurujuba (Baía de Guanabara) - RJ/Brasil. Brazilian Journal of Geophysics, 14(1): 51-58.

BAPTISTA NETO JA, SILVA CG, DIAS GTM \& FONSECA EM. 2011. Distribuição sedimentar da Lagoa Rodrigo de Freitas através de sísmica de alta resolução. Brazilian Journal of Geophysics, 29(1): 187-195.

BARROS MVS, ROLLNIC M \& WATANABE FK. 2017. Caracterização das principais feições superficiais de fundo e em subsuperfície no limite sudoeste da Baía de Macapá, canal do Norte, rio Amazonas. Trop. Oceanography, 45(1): 1-25.

BEXIGA GM. 2016. Estudo geoacústico para mapeamento de eco-caráter em registros sísmicos de alta resolução do interior da Lagoa dos Patos, RS, Brasil. Master Dissertation, Programa de Pós-Graduação em Geociências, Instituto de Geociências, Universidade Federal do Rio Grande do Sul, Brazil. 63 pp.

BOHRER MD. 2001. 0 aterro Praia de Belas e 0 aterro do Flamengo. Master Dissertation, Programa de Pesquisa e Pós-Graduação em Arquitetura, Universidade Federal do Rio Grande do Sul, Brazil. 237 pp. 
BORTOLIN EC. 2017. Paleovales quaternários na Lagoa dos Patos, Rio Grande do Sul, Brasil: preenchimento, evolução e influência na dinâmica lagunar. Doctorate Thesis, Programa de Pós-graduação em Geociências, Instituto de Geociências, Universidade Federal do Rio Grande do Sul, Brazil. 113 pp.

BORTOLIN EC, WESCHENFELDER J \& COOPER A. 2019. Holocene Evolution of Patos Lagoon, Brazil: The Role of Antecedent Topography. J. Coast. Res., 35(2): 357-368.

BRANCO FILHO CC. 2005. A orla do Lago Guaíba no município de Porto Alegre-RS: análise ambiental urbana e proposta de revitalização. 2005. Master Dissertation, Curso de Pós-Graduação em Geografia, Instituto de Geociências, Universidade Federal do Rio Grande do Sul, Brazil. 174 pp.

CARVALHO NO, FILIZOLA Jr NP, SANTOS PMC \& LIMA JEFW. 2000. Guia de práticas sedimentométricas. ANEEL, Brasília, Brazil. 154 pp.

CATANZARO LF, BAPTISTA NETO JA, GUIMARÃES MSD \& SILVA CG. 2004. Distinctive sedimentary processes in Guanabara Bay - SE/Brazil, based on the analysis of echo-character $(7.0 \mathrm{kHz})$. Brazilian Journal of Geophysics, 22(1): 69-83.

CECO - Centro de Estudos de Geologia Costeira e Oceânica. 1999. Projeto Sedimentação do Complexo Guaíba. Convênio CECO/UFRGS DVP/DEMAE, Porto Alegre, Brazil. 17 pp.

CHM - Centro de Hidrografia da Marinha. 2012. Lagoa dos Patos De Itapuã a Porto Alegre. N. 2111. Available on: <https://www.mar. mil.br/dhn/chm/box-cartas-raster/raster_disponiveis.html>. Access on: Jan. 09, 2017.

CLARKE J, MAYER L \& WELLS DE. 1996. Shallow-water imaging multibeam sonars: A new tool for investigating seafloor processes in the coastal zone and on the continental shelf. Mar. Geophys. Res., 18: 607-629.

DAMUTH JE. 1975. Echo character of the western equatorial Atlantic floor and its relationship to the dispersal and distribution of terrigenous sediments. Mar. Geol., 18(2): 17-45.

DAMUTH JE. 1980. Use of high-frequency (3.5-12 kHz) echograms in the study of near-bottom sedimentation processes in the deep-sea: a review. Mar. Geol., 38(1-3): 51-75.

DAMUTH JE \& HAYES DE. 1977. Echo character of East Brazilian continental margin and its relationship to sedimentary processes. Marine Geology, 24(2): 73-95.

DMAE - Departamento Municipal de Água e Esgotos. 2018. Lago Guaíba. Available on: <http://www2.portoalegre.rs.gov.br/dmae/default. php?p\seca0=197>. Access on: Feb. 13, 2018.

DNAEE - Departamento Nacional de Águas e Energia Elétrica. 1983. Mecânica de Correntes do Guaíba: Relatório Síntese. Ministério das Minas e Energia, Porto Alegre, Brazil. 61 pp.
FENSTER MS, FITZGERALD DM, BOHLEN WF, LEWIS RS \& BALDWIN CT. 1990. Stability of Giant Sand Waves in Eastern Long Island Sound, U.S.A. Mar. Geol., 91(3): 207-225.

HASENACK H. 2008. Diagnóstico ambiental de Porto Alegre: Geologia, Solos, Drenagem, Vegetação/Ocupação e Paisagem. Secretaria Municipal do Meio Ambiente, Porto Alegre, Brazil. 84 pp.

HATUSHIKA RS, SILVA CG \& MELLO CL. 2007. Sismoestatigrafia de alta resolução no lago Juparanã, Linhares (ES - Brasil) como base para estudos sobre a sedimentação e tectônica quaternária. Brazilian Journal of Geophysics, 25(4): 433-442.

KOTILAINEN AT \& KASKELA AM. 2017. Comparison of airborne LiDAR and shipboard acoustic data in complex shallow water environments: Filling in the white ribbon zone. Mar. Geol., 385: 250-259.

MARINO IK, SANTOS MAC \& SILVA CG. 2013. Processing of high-resolution, shallow seismic profiles, Guanabara Bay - Rio de Janeiro State, Brazil. Brazilian Journal of Geophysics, 31(4): 579-594.

MENEGAT R \& CARRARO CC. 2009. Manual para saber por que o Guaíba é um lago. Armazém Digital, Porto Alegre, Brazil. 108 pp.

NICOLODI JL. 2007. 0 padrão de ondas no Lago Guaíba e sua influência nos processos de sedimentação. Doctorate Thesis, Programa de Pós-graduação em Geociências, Instituto de Geociências, Universidade Federal do Rio Grande do Sul, Brazil. 179 pp.

NICOLODI JL, TOLDO Jr EE \& FARINA L. 2010. Dinâmica e ressuspensão por ondas no lago Guaíba e suas implicações nos locais de captação de água para abastecimento humano. Pesqui. Geocienc., 37(1): 25-39.

NICOLODI JL, TOLDO Jr EE \& FARINA L. 2013. Dynamic and resuspension by waves and sedimentation pattern definition in low energy environments. Guaíba Lake (Brazil). Braz. J. Oceanogr., 61: $55-64$.

NITSCHE FO, BELL R, CARBOTTE SM, RYAN WBF \& FLOOD R. 2004. Process-related classification of acoustic data from the Hudson River Estuary. Mar. Geol., 209(1-4): 131-145.

OLIVEIRA N. 2017. Caracterização de ocorrências de gás raso na plataforma continental interna do Rio Grande do Sul. Porto Alegre. Master Dissertation, Programa de Pós-Graduação em Geociências, Instituto de Geociências, Universidade Federal do Rio Grande do Sul, Brazil. $71 \mathrm{pp}$.

PAOLO FS \& MAHIQUES MM. 2008. Utilização de métodos acústicos em estudos de dinâmica costeira: exemplo na desembocadura lagunar de Cananéia. Brazilian Journal of Geophysics, 26(2): 211-225.

QUARESMA VS, BASTOS AC, LOUREIRO DV \& PAIXÃO S. 2011. Utilização de métodos geofísicos para mapeamento de lama fluída no porto de Tubarão, Vitória (ES-Brasil). Brazilian Journal of Geophysics, 29(3): 487-496. 
QUARESMA VS, DIAS GTM \& BAPTISTA NETO JA. 2000. Caracterização da ocorrência de padrões de sonar de varredura lateral e sísmica de alta frequência (3,5 e 7,0 kHz) na porção sul da Baía de Guanabara - RJ. Brazilian Journal of Geophysics, 18(2): 201-214.

SANTOS-FISCHER CB, CORREAAICS, WESCHENFELDER J, TORGAN LC \& STONE JR. 2016. Paleoenvironmental insights into the Quaternary evolution of the southern Brazilian coast based on fossil and modern diatom assemblages. Palaeogeography, Palaeoclimatology, Palaeoecology, 446: 108-124.

SANTOS-FISCHER CB, WESCHENFELDER J, CORREAA ICS, STONE JR, DEHNHARDT BA \& BORTOLIN EC. 2018. A Drowned Lagunar Channel in the Southern Brazilian Coast in Response to the 8.2-ka Event: Diatom and Seismic Stratigraphy. Estuaries and Coasts, 41: 1601-1625.

SCOTTÁ FC, ANDRADE MM, WESCHENFELDER J, TOLDO Jr EE \& NUNES JC. 2019. Descarga líquida e sólida em suspensão do sistema Guaíba. Pesq. Geoc. Unpublished.

SILVA Jr V0. 2017. Identificação geoacústica de ecofácies de fundo e subfundo da porção norte do Lago Guaíba, RS. Trabalho de Conclusão de Curso em Geologia. Instituto de Geociências, Universidade Federal do Rio Grande do Sul, Brazil. 64 pp.

SILVA AE, MENANDRO PS, NASCIMENTO KA, QUARESMA VS \& BASTOS AC. 2014. Interpretation of sedimentary processes using echo-character distribution: case study of Piraquê-Açu and Piraquê-Mirim estuarine system, Aracruz - ES (Brazil). Brazilian Journal of Geophysics, 32(2): 301-309.

SOUZA LAP. 2006. Revisão Crítica da Aplicabilidade dos Métodos Geofísicos na Investigação de áreas submersas rasas. Doctorate Thesis, Curso de Oceanografia Química e Geológica, Universidade de São Paulo, Brazil. 311 pp.
TOLDO Jr EE \& ALMEIDA LESB. 2009. Rio Guaíba. PROCEMPA, Porto Alegre, Brazil. 7 pp.

TOLDO Jr EE, DILLENBURG SR, CORREA ICS \& ALMEIDA LESB. 2000. Holocene sedimentation in Lagoa dos Patos Lagoon, Rio Grande do Sul, Brazil. J. Coast. Res., 16(3): 816-822.

VERONEZ Jr P, BASTOS AC, PIZZIN BF, GAVA RD, QUARESMA VS \& SILVA CG. 2009a. Sonar de varredura lateral e sísmica de alta resolução aplicados no estudo de ecofácies na Baía de Vitória - ES. Brazilian Journal of Geophysics, 27(3): 411-425.

VERONEZ Jr P, BASTOS AC \& QUARESMA VS. 2009b. Morfologia e distribuição sedimentar em um sistema estuarino tropical: Baía de Vitória, ES. Brazilian Journal of Geophysics, 27(4): 609-624

WESCHENFELDER J, CORREAA ICS, ALIOTTA S, PEREIRA CM \& VASCONCELLOS VEB. 2006. Shallow gas accumulation in sediments of the Patos Lagoon, southern Brazil. An. Acad. Bras. Ciênc., 78(3): 607-614.

WESCHENFELDER J, CORRÊA ICS, ALIOTTA S \& BAITELLI R. 2010. Paleochannels related to late Quaternary sea-level changes in Southern Brazil. Braz. J. Oceanogr., 58: 35-44.

WESCHENFELDER J, BAITELLI R, CORRÊA ICS, BORTOLIN EC \& SANTOS-FISCHER CB. 2014. Paleochannels related to late Quaternary sea-level changes in Southern Brazil. J. South Am. Earth Sci., 55: 83-93.

WESCHENFELDER J, KLEIN AHF, GREEN NA, ALIOTTA S, DE MAHIQUES MM, AYRES NETO A, TERRA LC, CORRÊA ICS, CALLIARI LJ, MONTOYA I, GINSBERG SS \& GRIEP GH. 2016. The control of palaeo-topography in the preservation of shallow gas accumulation: Examples from Brazil, Argentina and South Africa. Estuar. Coast. Mar. Sci., 172: 93-107. 